\title{
Mortgage and mortgage lending as a tool for financial recovery of the modern Russian economy
}

\author{
Svetlana Rybak $^{1 *}$ \\ ${ }^{1}$ Don State Technical University, Gagarin sq., 1, Rostov-on-Don, 344003, Russia
}

\begin{abstract}
The article is devoted to the institutional analysis of the problem of improving the legal regulation of mortgage relations in Russia in modern conditions in the presence of a rather limited financial capacity of the population in modern conditions to purchase real estate or housing. In this regard, the mortgage becomes the most necessary tool to ensure the socio-economic development of society, its stable and sustainable development. The formation of the property base currently generates a corresponding demand in the real estate market, and develops a corresponding interest among consumers in mortgage lending. At the same time, the emerging financial mechanism of mortgages also ensures the formation of the solvency of not only the population, but also other market participants, so that this market segment becomes not only in demand, but also successfully developed. Considering this problem, the author sought to update the scientific, theoretical and practical interest in this topic and to reveal the problems that hinder the development of mortgages as an important factor in the financial recovery of the modern market economy.
\end{abstract}

\section{Introduction}

The economic sphere is currently a fairly integral and constantly changing subsystem of society, generated by the objective need for continuous reproduction of the economic product, which will largely be able to provide the building of material potential, which, in the context of the transformation of economic relations [1], will provide an opportunity for a real rethinking of the post-Soviet economic paradigm and, thereby, determine the new role of the state in the economic and economic sphere. Of course, a new concept is needed and, on its basis, a new model for the functioning of the economic sphere, taking into account the location of the state in the common world and optimizing on this basis, including socio-economic processes. The changes associated with the transition of Russia to the system of market relations affected a large number of socio-economic relations in society. In particular, they touched on the real estate market, which aims to connect buyers and sellers and has a complex structure. It was the real estate market that showed the most painful reaction to these changes, an important reason for which was the basic needs of people - the need for housing. Every day, more and more citizens, enterprises, and

\footnotetext{
*Corresponding author: Svetoch_2504@mail.ru
} 
organizations enter into relations related to participation in real estate transactions, thanks to which there is an active formation and development of the real estate market in Russia. The formation of the real estate market in the Russian Federation is a historical process. The first stage is connected with the fact that due to the transition of Russia to the path of market relations, a course was taken for the financial recovery of the modern real estate market, for its full formation and development. At the same time, the strategic basis for the development of which has recently become mortgages and mortgage lending. Mortgages today are a powerful tool, thanks to which there is a balanced demand not only in the real estate market [2], but also housing, which allows the state to optimize the social sphere. The provision of citizens with comfortable housing is one of the most obvious indicators of the state's well-being. There is also an inverse relationship between them. The right to housing is recognized by the international community as an element of the right to a decent standard of living. It is predetermined by the market economy that the majority of citizens are faced with the fact that they need to independently provide themselves with housing using appropriate mechanisms (through their personal savings, or using mortgage lending).

Mortgages and mortgages occupy an important place among other ways of securing obligations, and even at the present time, it is impossible to accurately determine their nature and assign them a place among obligations or property rights. Such features of the pledge right as: protection against anyone in whose possession the pledged thing will be, the concentration of the right of the pledgee regarding the sale of the thing and the use of the value - present considerable difficulties for determining the legal nature of this right.

\section{Materials and methods}

In order to comprehensively study the problem under consideration, attention should be focused on methodological approaches, with the help of which it became possible to comprehensively study this problem. First of all, the comparative legal method, complex and systemic analysis, historical and legal method, as well as methods of formal and dialectical logic are used: complex and problematic types of analysis, synthesis, induction, deduction.

The carried out analysis based on the system-structural, functional, and comparative approaches allowed to reveal and substantiate the scientific and theoretical concepts of the modern understanding of mortgage and mortgage lending in the study. The given categorical characteristics of the modern model of mortgage lending reflect forming in the Russian legal space of the institutional legal environment affecting the state and social processes of modern Russian society. The methods of formal and dialectical logic were used throughout the work due to their versatility and ease of use.

Thus, the achieved results of the work are stipulated by the possibility and feasibility of their usage in the scientific research activity in the subsequent development of the theoretical and applied problems of mortgage and mortgage lending, in the context of the financial recovery of the Russian economy.

\section{Results and discussion}

With regard to the discussion of the problem of the nature of mortgages, it should be noted that to date, it continues to be generally quite controversial [3]. The first point of view is that the pledge is considered as a real right together with the right of ownership and other rights [4]. It was very widespread in pre-revolutionary Russia. In the nineteenth and early twentieth centuries, many scientists argued for the absolute primacy of the real-legal content of collateral relations [5]. Among the representatives are such famous scientists. 
This was also reflected in the legislative acts of those times: the Russian Civil Code, the German Civil Code, and also the Italian and Austrian laws, which at that time referred to the pledge as real rights. The real nature of the pledge was justified, first of all, by the fact that the right of pledge always follows the thing regardless of the change of owner [6].

Thus, Mr. Dernburg defined a pledge in a narrow sense as a right to another person's bodily thing that serves as a security for a debt claim, authorizing the lender to sell it for his own satisfaction. At the same time, he notes that in this form the idea of collateral has found the perfect expression. The main sign that a pledge is a real right is that the right of pledge extends to the thing directly and for a long time and remains unchanged regardless of the change of owner. It follows from this definition that the lien is strictly accessory. It also does not allow the pledge of property rights. But this is the concept of a pledge in the proper sense. In a broad sense, Mr. Dernburg says that this is an unchangeable right to a property object, from which you can get satisfaction in the event of late payment of a debt. In this form, it can be established both through the transfer of property rights and other property rights. In addition to material objects, it can also apply to debt claims and easements.

Adopted in the XIX century the Charter on Banks included in the Russian legislation a provision on the sale of mortgaged property at auction. But this charter was ineffective in practice in connection with the consolidation of the right of debtors to return the pledged thing even after the sale of the property at public bidding.

At the same time, the regulations on small loan institutions comes into force in the Russian Empire, which became a catalyst for the rapid development and creation of private collateral institutions.

By the beginning of the XX century, the institution of mortgage in Russian law was formed in its almost modern sense. At the same time, the procedure for concluding transactions on the pledge of real estate and, in particular, land plots has made serious progress. The pledge of real estate should be made only in a notarized form.

There were also the basic principles of mortgages: leaving the debtor with all the rights of the owner, with a limited right of disposal; after the pledge of land, the satisfaction of the creditor's claims was carried out as a result of the sale of property at public auction and only on the amount of the debt; the state registration of mortgage transactions was public and reliable.

The Soviet period of history did not contribute to the development of the mortgage institution and an unprecedented interest in it began to manifest itself only from the beginning of the $90 \mathrm{~s}$ of the $\mathrm{XX}$ century, during the beginning of the reform of civil legislation, with the approval of the right of private ownership of land in the conditions of the modern Russian state.

Modern supporters of the real-legal nature of the pledge in most cases use the arguments set out by pre-revolutionary civil scientists.

In general, the arguments of the supporters of the real-legal nature of the pledge are reduced to the following features [7]. First, it is the following of the right of pledge after the thing - having a thing as its object, it follows it everywhere, being a concomitant right of the droit de suite. This is confirmed by the civil legislation. Secondly, in the case of collateral, there is an order of seniority of creditors, which is not typical for the nature of obligations. Thirdly, the pledgee is endowed with a number of proprietary methods of protecting the pledge right, including the right to bring vindication and negative claims against violators of his rights.

Another point of view is that the pledge has a binding legal nature. The pledge, therefore, establishes only a binding claim against the debtor. This position was taken by such legal scholars as K. N. Annenkov, M. I. Braginsky, V. V. Vitryansky, and V. M. Khvostov. 
Another proponent of the legally binding nature of the pledge is V. V. Vitryansky He particularly notes the fact that the subject of the pledge can be in addition to things and property rights. However, the latter cannot be an object of real right under any circumstances.

Currently, there are also lawyers who adhere to the position of the dual nature of the pledge, not defining it with certainty either as a property or as a law of obligation.

In view of the above positions, it seems that the legal nature of the pledge is currently tending to the nature of the obligation. This is evidenced, first of all, by the fact that the pledge cannot be called with certainty an absolute legal relationship, because in this respect two counterparties are clearly distinguished - the pledger and the pledgee with their inherent rights and obligations[8].

Another important evidence is the possibility of pledging property rights, which does not correlate in any way with the proprietary nature. The third circumstance in favor of the nature of obligations is that it is possible to assign a pledge to another person by way of cession. As a result of the pledge of property, the right arises not to the thing itself, but the right to recover the debt from the value of this thing. This is confirmed by the position worked out by the joint Plenum of the Armed Forces and the Supreme Arbitration Court of July 1, 1998 No. 6/867. Clause 46 of this Plenum confirms the impossibility of transferring the property that is the subject of the pledge into the ownership of the pledgee.

At the same time, it should be taken into account that the legal nature of the pledge does not exclude its real-legal features. For the stability of the position of the creditor - pledgee, the real-legal methods of protection - vindication and protection of the rights of the pledgee from violations not related to the deprivation of possession-are introduced into the construction of the pledge. In this question, we can agree with the position of A.V. Fioshin, who represents a pledge in the form of a legal pyramid, the projection and basis of which are the legal elements of obligations, and the facets are real. As for the mortgage, as a special type of pledge, where the subject of the pledge is real estate, recently the views on it as a real right have become more and more pronounced.

It should be borne in mind that the very essence of collateral and mortgages is to ensure the proper performance of the obligation and not in the exercise of domination over the thing or any real right. As a result, the following conclusion should be drawn: a mortgage, as well as a generic institution for it-a pledge, in any case has a core in its content-a relative legal relationship, is temporary and accessory in nature to secure the main obligation. At the same time, the position of the mortgagee is strengthened by absolute ownership protection. At the same time, it is worth noting the prospective desire of the legislator to move from the mandatory concept of mortgages to the real concept.

The main distinguishing feature of a mortgage, which allows you to distinguish it from other types of collateral, is its subject, which is real estate.

In addition, in accordance with Part 2 of Article 7 of the Federal Law "On Mortgages", it is possible to pledge a share in the right to immovable property, and the provisions of Article 6 of this law allow for the restriction of mortgage not only the right of ownership, but also the right of economic management.

The analysis of these provisions of the law indicates the ambiguity of the mortgage legislation in relation to the definition of the subject of the mortgage. In this regard, it is necessary to bring the concept of mortgage, enshrined in Part 1 of Article 1 of the Federal Law «On Mortgage», in line with the real state of affairs in mortgage relations by directly including in the subject of mortgage property rights, the object of which is real estate. Some lawyers suggest a diametrically opposite solution to this issue - to completely exclude from the mortgage legislation the rules governing the pledge of property rights to immovable things, and create a special chapter in the general rules of the paragraph of the Civil Code of the Russian Federation on collateral. It seems that a more logical solution would still be 
to develop the pledge of property rights to real estate in the form of a mortgage due to the fact that property rights to real estate have high liquidity, like real estate itself, and require a stronger position of the mortgagee and the publicity of the encumbrance. This is especially true for mortgages of lease rights to land plots, since often land plots are leased for a long time.

A mortgage in accordance with the Civil Code (paragraph 2 of Article 334) is a pledge of land plots, buildings, structures, apartments and other immovable property.

In connection with the development of the residential real estate market, after the transition of Russia to the system of market relations, there is an urgent need for the development of mortgages. This direction has become the most actively developed in Russia since the late 90s. In particular, in 1997, the Mortgage Development Institute, the Agency for Housing Mortgage Lending (AHML), was established. Then the mortgage boom begins in Russia, which was accompanied by an active regulatory consolidation. At the same time, the Russian legislator followed the so-called" narrow path", limiting the scope of mortgages only to property collateral, that is, real estate collateral. Although in many foreign countries, mortgage lending is widely practiced against collateral, when a variety of objects are purchased with the funds received: these can be luxury items, additional housing, and business facilities. In some countries, mortgages are issued for education. Although this practice has not been developed in Russia.

The development of mortgages since the beginning of the two thousandth years was quite understandable, since the country's market is stabilizing, refinancing rates and the level of inflation are decreasing, and these phenomena create such conditions that allow the development of mortgage housing lending in the Russian Federation. The main way to improve housing mortgage lending is to create more affordable mortgages for the population. So, the main measures for the formation of affordable mortgages are highlighted.

- Improvement of mortgage lending schemes:

- Reduction of the mortgage rate. According to many scientists, high rates make the loan meaningless for borrowers. Therefore, the key rate of the Central Bank of Russia plays an important role in this situation, as it affects the setting of loan rates. It follows that the demand for a mortgage depends on the rates, and the lower the rate, the greater the demand for a mortgage.

- Increase in the term of mortgage lending;

- Reduction of the down payment on the loan;

- Development of preferential lending programs, that is, the development of programs for individual segments of the population. Mortgages are currently available to people who have average earnings, therefore, they are not available to a certain category of the population who have lower-than-average earnings. And in order to create an affordable market for housing mortgage lending, it is necessary to develop special preferential programs, such as military mortgages, mortgages with maternity capital or mortgages for state employees.

- Development of the mortgage securities market. In modern conditions, lending is an integral part of raising funds and credit operations are the most important activity of banks. Today, lending is the main form of borrowing by enterprises. In the stock market, lending is the most profitable item of creditors ' assets, but also the most risky. Credit risk has always been and remains the main type of bank risk. Credit risks are understood as the risk of nonrepayment or delay in payment for a banking service. This type of risk exists in the case of loan and related transactions that are reflected on the balance sheet. Since it is impossible to be one hundred percent sure of its effectiveness when entering into a loan agreement, we can say that each transaction has the property of «riskiness».

First, there is always the risk of unforeseen circumstances. 
The main and most common are the loss of property that the borrower has pledged, its insolvency, as well as the bankruptcy of the guarantor. Secondly, there is a possibility that when the deadline for payment of obligations comes, the borrower will not want to pay. Third, the modern market contains a large number of risky situations, which in turn contribute to the loss of the credit institution's assets.

The state of crisis leads to the inadequacy and inability to use the previous tools to achieve the desired result, which creates unforeseen circumstances and the emergence of new problems.

The Russian banking system cannot be an exception. Among the risks to the financial stability of commercial banks, external vulnerabilities are of high importance. Among the key external factors today, a special place is occupied by the weak growth of disposable incomes of citizens and, as a result, the problem of increasing the debt burden of the population.

In order to control the situation in the consumer lending market, the Bank of Russia regularly introduces measures designed to reduce the growth rate of lending to citizens. For example, to assess the degree of creditworthiness of the population, the Bank of Russia introduces an indicator of the debt burden of citizens.

The Bank of Russia, there has been a slowdown in unsecured consumer lending. For 6 months of application of measures of state regulation of consumer lending, the annual growth rate of unsecured loans as of 01.10 .2019 decreased from $25.3 \%$ to $23.5 \%$. The growth of unsecured consumer lending in 2020 slowed down against the background of stricter requirements of lenders to potential borrowers and a shift in banks ' interest in collateral lending in the context of the pandemic and uncertainty in the dynamics of household incomes. The total amount of mortgage debt exceeded 9 trillion rubles as of 01.01.2021.

The share of commercial banks in which the dynamics of bad loans has a negative characteristic is $13 \%$ at the assessment date.

It should be noted that the analysis of data from credit bureaus allows us to see that the growth of the debt burden of the population is primarily due to an increase in new borrowers who did not have a loan before. So, as of $01.10 .2019-45 \%$ of borrowers have a first consumer loan. In 2020, despite the pandemic and restrictive measures, the mortgage market set a new record: credit institutions issued 1.7 million mortgage loans totaling $\$ 4.3$ trillion. rubles. This dynamic was caused by a number of measures of the state regulator applied until January 2019 and from April 2020 (anti-crisis preferential state program of lending for the purchase of housing in new buildings). Namely, measures aimed at easing banks ' lending standards by providing loans to borrowers with an increased debt burden. Simultaneous use of multiple credit products is becoming increasingly common. Thus, the share of borrowers who have other credit products in addition to a mortgage loan has increased in four years from $39 \%$ to $46 \%$, as of 01.10 .2019 .

It is obvious that such a credit policy in relation to consumer lending can lead to an uncontrolled increase in non-payments on consumer loans.

The measures taken by the Bank of Russia to influence the stability factors of the banking system can be assessed as sufficient.

For example, the Bank of Russia has established allowances to the risk coefficients for consumer loans, depending on the indicator of the borrower's debt load, which are applied to loans issued since October 2019. It is worth paying attention to the fact that external and internal restrictions on business and consumer activity in connection with the crisis phenomena caused by the virus pandemic of 2019-2021 may lead to a significant weakening of economic activity in Russia and in the world.

This determines the need for the state regulator to take measures to support businesses and the population that are most affected by the restrictions. 
In the chart we can see the dynamics of mortgage lending in Russia over the last period (Fig. 1).

In the primary housing market

In the secondary housing market

In the luxury real estate market

On the other property market

$$
\begin{array}{r}
\square 2020 \text { Г } \\
\square 2019 \Gamma \\
\square 2018 \Gamma
\end{array}
$$

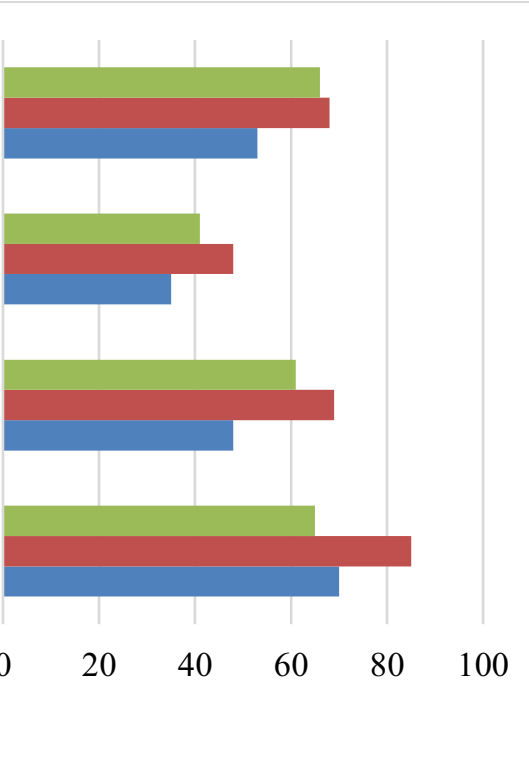

Fig. 1. The dynamics of mortgage lending in Russia.

The data presented in this diagram are promising and clearly demonstrate to us the peculiarities of mortgage development in the Russian economy and the prospects for its further development.

The support measures taken will be effective not only during the crisis of the viral pandemic, but also during the recovery period. To implement these measures, it is necessary to determine the list of economic sectors to which enterprises will apply a special procedure for accounting for quality assessment and the formation of reserves for possible losses.

Obviously, such industries can become:

- housing construction. Bank lending will become the main tool for attracting capital to the activities of construction companies;

- transport-related activities;

- activities for the provision of household services to the population.

For enterprises in these industries, it is proposed to apply a standard assessment of the quality of debt service, regardless of the assessment of the financial situation of the borrower. This measure will be aimed at forming reserves of commercial banks for losses, which will serve as a safety cushion not only during the growth of the crisis phenomena of our time, but also in the subsequent period of economic recovery.

An integral way to reduce the risk of a bank loan is to create reserves to cover the possible loss of credit activity. In the most common methods of credit risk analysis, you should choose the following: the probability of default of the borrower, calculated on the basis of the formula for determining the main relationship between the main financial performance indicators, the rating of borrowers of commercial banks.

Risk management experts intuitively assess the concentration of risk based on the volume of investment in a particular industry or group of industries, based on the credit limits for one or a group of related borrowers. 
It should be noted that it is currently not enough to use fixed limits that do not take into account the relationship between risk and income. For example, one of the main ways to improve the efficiency of bank lending is to directly restrict the issuance of loans and combine them with a dynamic analysis of their effectiveness.

In the process of determining credit risk, the combined method can be used to clearly understand the organizational structure and product structure of commercial banks and to form a risk-specific business process that is segmented according to individual business processes. Building a risk map is the main method of promoting the result of risk identification. The risk map is based on a comparison of the organizational structure and product range of commercial banks with the credit risk classification chosen by commercial banks, which ultimately leads to the formation of a generalized list of risk positions of commercial banks.

At the present stage of development of the Russian economy, which is characterized by recession and financial instability, the key factor of normal functioning for all organizations, including credit organizations, is the risk management process.

The bank's credit risk management is not a chaotically applied intermittent measures, but an organized and clear sequence of actions of the bank's managers, which consists of the following stages.

The first stage is aimed at determining the causes of credit risks and includes the detection, types and identification of credit risk, which is the identification of external and internal factors of credit risk, its scale and concentration.

The following main factors should be noted, which are the most common reason for the formation of credit risks:

- the threat of loss of liquidity of the provided loan;

- certain qualities of the borrower;

- inability to create a full-fledged cash flow by the borrower;

- too high concentration of loans in certain industries or sectors of the economy;

- currency risk of the loan portfolio;

- excessive diversity of the loan portfolio;

- formation of large portfolios of non-performing loans;

- unsatisfactory degree of qualification of employees of the credit institution.

The second stage is the risk assessment, which consists of determining the size of possible losses, that is, calculating an easily explained and accurate quantitative measure of risk.

The third stage is the selection of a risk management strategy, which may include:

- decision to accept the risk;

- complete or partial refusal of any actions and activities that are associated with risk;

- reducing the degree of risk.

The fourth stage is to determine the ways and methods of risk management. This process involves comparing and correlating the estimated credit risk with the overall policy of the credit institution and applying various methods for management aimed at reducing the amount of credit risk.

When creating a credit risk management system of the bank, it is necessary to observe certain principles:

1. The integrity of the bank's information database, which will provide information on the situation of enterprises in different industries. This will allow the bank to calculate and assess its risks more correctly [9].

2. For all the bank's risks, the structure of the management system should be similar and consistent;

3. Coordination of risk management. 
The fifth stage is risk monitoring, which is an assessment and control of the effectiveness of methods and tools that are used to manage credit risks and change the degree of credit risk.

Also at this stage, various methods are developed and implemented to control the current types of bank risks and forecast (anticipate) possible future risks of the organization.

Having considered all the stages of a bank's credit risk management, we can give the following definition to this concept - the risk management process is nothing more than a system of measures aimed at identifying, analyzing, managing and controlling credit risks [10]. that allow a credit institution to reduce or even avoid losses and losses arising from the occurrence of credit risks.

In the European Union, the UK mortgage market is often used as a backbone due to the significant size and level of adoption of mortgage by-products, which is reflected in the large number of loan types available. With a total value of $£ 1.499 \mathrm{bn}$ in home loans in 2019, the UK mortgage market is the largest in Europe [11].

\section{Conclusion}

Today, mortgage is considered as one of the most affordable and popular ways to purchase a home. In the context of growing real estate prices (especially in the central part of Russia) and the downward dynamics of the real incomes of citizens, the development of the mortgage lending system is becoming one of the priority tasks of the country's social development.

Mortgage lending, as one of the activities within the framework of the domestic financial market, still needs control by the state - this concerns both the need to increase the transparency of relations arising within it, and supervisory measures aimed at developing competition within the financial sector of the economy.

Experts believe that the mortgage market will face difficult times [12]. Every month fewer and fewer people can afford to get a mortgage loan, housing prices are rising, and many construction companies cannot get project financing from banks. An equally important trend is that Russians take out consumer loans, and then use them for an initial mortgage payment; their number is $3 \%$ of all mortgage holders. All this will negatively affect the state of the mortgage lending market in the near future [13].

Thus, mortgage as an extremely recognizable institution of civil law was formed in ancient law, but has not lost its relevance to widespread use in modern law. In prerevolutionary Russia, the mortgage lending system functioned successfully and was accessible to many segments of the population. Then, as you know, for almost 70 years the mortgage mechanism remained unclaimed in our country. While all over the world this institution has been successfully developing. At the same time, the main indicators that fix this process can be as follows. First of all, this is the potential for development and streaks and mortgage lending as a manifestation of its quantitative and qualitative characteristics. In addition, among the indicators, one can single out the so-called subjective assessment based on the degree of satisfaction of consumers of mortgage loans in accordance with their intended purpose (satisfaction with the acquired housing or other real estate objects). The presence of these indicators clearly demonstrates to us the level of development of property relations that can extinguish negative contradictions between the real needs of people and the level of their material support [14], which will create a reasonable balance between the social and economic spheres in the modern development of the Russian state in the mechanism of its sustainable and prospective development [15], especially during the period of overcoming the consequences of the global economic crisis. 


\section{References}

1. S. C.-Y. Leu, M. L. Robertson, Economic Modelling, 94, 483-500 (2021), DOI: doi.org/10.1016/j.econmod.2020.09.011

2. P. Mathew, P. Issler, N. Wallace, Energy Policy, 150, (2021), DOI: doi.org/10.1016/j.enpol.2021.112137

3. Y. Deng, Q. Gu, J. He, Pacific-Basin Finance Journal, 12 (2020), DOI: doi.org/10.1016/j.pacfin.2020.101378

4. D. Bezemer, A. Samarina, L. Zhang, Journal of Banking \& Finance, 113, 105760 (2020), DOI: doi.org/10.1016/j.jbankfin.2020.105760

5. A. Rojas, Journal of Empirical Finance, 62, 220-233, (2021), DOI: doi.org/10.1016/j.jempfin.2021.04.002

6. C. M. Vojtech, B. S. Kay, J. C. Driscoll, Journal of Financial Intermediation, 44, 344368 (2020), DOI: doi.org/10.1016/j.jfi.2019.100846

7. J. Kim, Journal of Economic Dynamics and Control, 121, 104021 (2020), DOI: doi.org/10.1016/j.jedc.2020.104021

8. M. Iosifidi, E. Panopoulou, C. Tsoumas, Journal of Financial Stability, 53, 139-157 (2021), DOI: doi.org/10.1016/j.jfs.2021.100851

9. I. de la Fuente, E. Navarro, G. Serna, International Review of Economics \& Finance, 74, 239-252 (2021), DOI: doi.org/10.1016/j.iref.2021.03.001

10. L. Diaz-Serrano, International Review of Economics \& Finance, 63, 412-422 (2019), DOI: doi.org/10.1016/j.iref.2019.05.003

11. D. Buckner, K. Dowd, Economics Letters, 197, 109651 (2020), DOI: doi.org/10.1016/j.econlet.2020.109651

12. N. Bhutta, D. Ringo, Journal of Monetary Economics, 118, 195-211 (2020), DOI: doi.org/10.1016/j.jmoneco.2020.10.001

13. J. Horvath, P. Rothman, Journal of International Money and Finance, 102370 (2021), DOI: doi.org/10.1016/j.jimonfin.2021.102370

14. T. Shi, Y.-T. Lee, Insurance: Mathematics and Economics, 98, 68-82, (2021), DOI: doi.org/10.1016/j.insmatheco.2021.02.008

15. S. Rybak, I. Krygina, E3S Web of Conferences, 210, 18039 (2020), DOI: doi.org/10.1051/e3sconf/202021018039 